\title{
ISLAMIC HUMANISM IN INDONESIAN CONTEXT: Discourse Analysis of Nationality Problems in Indonesia
}

\author{
Wahyudin, ${ }^{*}$ Agus Maimun, ${ }^{* *}$ and Mat Jalil \\ * Institut Agama Islam Negeri Metro Lampung, Indonesia \\ ** Universitas Islam Negeri Maulana Malik Ibrahim Malang, Indonesia \\ E-mail: wahyudin@metrouniv.ac.id
}

\begin{abstract}
The thought of humanism originated in Athens. As a universal ideology, humanism is the foundation of modern civilization in the western and the eastern world. As an ideology, humanism is adopted by many third world countries, including Indonesia. Although there have been many discussions on Humanism, studies on Humanism in Islam perspective related to tolerance, freedom, and equality in Indonesia's context have not been carried out. This study attempts to fill that gap including the values of tolerance, freedom, and equality of rights in Indonesia. It is conducted to discover the Islamic humanism developed in Indonesia. The results of the study are: (1) the Islamic humanism is very relevant in Indonesian context which has life philosophy of Pancasila; (2) tolerance as part of Islamic humanism still stands tall in Indonesia because people assume that it has high enthusiasm for safeguarding human dignity; (3) freedom of society in religion, expressing opinion, politics, and other national and state life activities has been guaranteed by the law, although there are still some restrictions by the government on freedom of society; (4) equality rights wise, there are still some Indonesian people who still get unfair law treatment, for example many low-economic level citizens who steal trivial items get severe penalties,
\end{abstract}


while the corruptors stealing bigger amount of money often roam freely without supervision.

Pemikiran humanisme berasal dari Athena. Sebagai ideologi universal, humanisme adalah dasar dari peradaban modern di dunia barat dan dunia timur. Humanisme sebagai ideologi, banyak diadopsi oleh negara dunia ketiga, termasuk Indonesia. Meskipun ada banyak studi tentang humanisme, studi serupa dalam perspektif Islam terkait toleransi, kebebasan, dan kesetaraan dalam konteks Indonesia belum banyak dilakukan. Studi ini bertujuan untuk mendeskripsikan humanisme dalam perspektif Islam termasuk nilai-nilai toleransi, kebebasan, dan persamaan hak yang terjadi di Indonesia. Dengan ini, diharapkan humanisme Islam yang berkembang di Indonesia dapat diketahui secara jelas. Hasil studi adalah: (1) humanisme Islam sangat relevan dalam konteks ke-Indonesiaan yang memiliki falsafah hidup Pancasila; (2) toleransi sebagai bagian dari nilai humanisme masih berdiri tegak di bumi nusantara, karena masyarakat mengganggap bahwa toleransi memiliki semangat yang tinggi untuk menjaga keluhuran dan martabat kemanusiaan; (3) kebebebasan masyarakat dalam beragama, berpendapat, berpolitik, dan berbagai aktifitas kehidupan berbangsan dan bernegara lainnya, di Indonesia telah dijamin undang-undang, meskipun masih ada beberapa pembatasan oleh pemerintah terhadap kebebasan masyarakat; (4) dalam hal persamaan hak, masih ada beberapa masyarakat Indonesia yang merasakan perlakuan yang tidak adil di depan hukum, sebagai bukti banyak orang kecil yang mencuri barang yang sepele mendapatkan hukuman yang berat, sedang para koruptor uang rakyat yang jumlahnya relatif besar seringkali berkeliaran bebas tanpa pengawasan.

Keywords: equality right; freedom; Islamic humanism; tolerance

Received: May 6, 2019; Accepted: December 17, 2019

\section{Introduction}

Historically, humans have always been faced with the demands and challenges that were never eventually resolved, but still faced and sought to solution from generation to generation throughout their existence as a dignified human being (Setjoatmodjo 1984, 129). Therefore, in the history 
of human development, education has always received major and serious attention to advance life in line with the demands and progress.

Humans were created by God as creatures in the best form more than other creatures, such as animals and plants. Furthermore, God gives humans privileges in abilities to distinguish and receive various knowledge, to come up with new ideas and thoughts that also make them able to rule the world. For this reason, humans must be distinguished from animal and vegetable or plants (Syaifullah 1984, 141-2).

Titus places humans as animal organisms that can study themselves, can interpret life forms, and can investigate their existence meaning (Muhaimin and Mujib 1993, 31). God's provisions regarding humans' qualities have consequences, that in their life adventure, humans must remain in the 'best possible form' and do not lead to 'the lowest position'. The implication is that education is expected to secure human quality to avoid all obstacles.

The form of obstacle from humans is against God's teachings. He always shows what is good and safe for humans' life in the world and the hereafter. Sometimes they forget that in fact, they are responsible for protecting themselves from despicable life so they can achieve life goals. The realistic goal of human life is to enhance the dignity as human beings (Soelaeman 1988, 73). Thus they became global citizen with a dignified social life (Gazalba 1978, 21).

Humans are consisted of spirit and togetherness. Spirit cannot deal with the body. Instead, the body and all forms of substance can do their job properly if humans can balance both factors (Daudy 1983, 172). In life where situation constantly change and where there are different in opinion, beliefs, and views, humans will always involve. Therefore, life should be based on religious values, so that humans have high dignity (Drijakara 1969, 7).

In managing real life, humans seem to give full confidence to the ratio to produce values and regulations that are concretely useful to save lives (Tamara and Hashem 1996, xiii-xiv). Humans always try to make themselves better than their humanity position to achieve happiness in life (Ali 1984, 52). They do not want to fall to a low degree, so they must equip themselves with a set of knowledge about human values.

Human values are built based on humanism thinking. Humanism is a discussion of human affairs from all sides, in terms of sociology, psychology, anthropology, theology, phenomenology, and so forth (Boisard 
1980, 92). The thought of humanism originated in Athens, but as a universal understanding. Humanism became the foundation of modern civilization in the western and eastern world. Humanism was originally a strong reaction to scholastic philosophy and Christianity which was very dogmatic and shackled human thought (Syariati 1984, 2). However, now humanism has been adopted by many third world countries, including Indonesia.

Islamic humanism is developed in hope that human controlling other human beings will not occur which can lead to acts of discrimination and anarchism as well as unethical actions because they are not in line with human values. If this is not controlled well, it will result in human powerlessness in dealing with their lives (Rahardjo 1987, 170).

It appears that humans ruling humans as a form of modern colonialism occurs in Indonesia. It happens because of oppression, discrimination, anarchism, radicalism, human's oppression, liberation, and so on. We can witness these indirectly through mass media, online media, television, or directly within surrounding community. The examples of these problems are forbidding Muslim citizens to live in certain area, the emergence of non-native movement, and dispute between groups triggered by simple problems. All of those still happened even though Pancasila has affirmed the third principle "Persatuan Indonesia (The unity of Indonesia)" and also the motto "Unity in Diversity".

This condition contradicts the values of Pancasila which uphold the dignity of humanity and unity. It is also incompatible with the second principle of Pancasila, "Kemanusiaan yang adil dan beradab (Just and civilized humanity)" which is the basic value of community's harmony and peaceful life. If the Indonesian people are known for their attitude to maintain eastern values, they will uphold the values of humanism sincerely. In reality, the implementation of values of humanism in Indonesia tends to imitate the western concept, such as liberal, secular, individual, radical, and humanism anarchism. Those humanism concepts contradicts the values of Pancasila and also eastern values.

From these thoughts, the study of Islamic humanism in Indonesian context is very important. Therefore, this study wants to obtain information that is different from previous studies. A study by Misbah focused on the values of humanism in an Islamic perspective. He explained that Islam which carries the big mission, rahmat li al-âlamîn certainly does not justify violation. It means that if bad behavior is done by one Muslim, it will affect 
the whole Muslims negatively whereas there are more Muslims who are religious devotees (Misbah 2014). Other studies highlight the features of religious humanist education, generally found in pesantren which are shown by an attitude of love towards fellow human beings such as kyai and santri who have awareness that humans are God's creation (Arifin 2014). In line with this, Subiyantoro's study found that the actualization of religious and values of humanism increased. Educational patterns could give students freedom in self-actualization. Students became more open to their teacher as well as felt close. They also became more creative and achievers in their field of interest (Subiyantoro et al. 2013). Fakhruddin found that the development of modern education which tends to separate spiritual and physical education leads to immoral acts which then gave rise to the concept of humanization in western paradigm. The substance of humanity is then failed to achieve (Fakhruddin 2016). The study conducted by Nelson and Dardiri found that the values of humanity and inclusiveness were inherently deeply embedded in the world of pesantren. Therefore, it is not true to find that pesantren give birth to an exclusive generation of mujahid, and that only santri deserves heaven (Nelson and Dardiri 2016).

\section{The Paradigm of Humanism: Islamic Perspective}

The concept of humanism in Islam is theocentric that God as the center of everything for $\mathrm{He}$ is The Creator. The holy book of Islam explained that the creation of Adam as a symbol of man on earth is the culmination of creation (Syariati 1984, 3). Allah says "We have created you (i.e. Adam) from dust, then from a nutfah (mixed drops of male and female sexual discharge i.e. the offspring of Adam), then from a clot then from a little lump of flesh-some formed and some unformed- that We may make (it) clear to you (i.e. to show you Our Power and Ability)" (Q.S. al-Hajj [22]: 5).

Based on the concept that humans are created from two different elements which are two-dimensional and considered to be low and abject. Humans who are inclined towards spiritual concepts will go to the highest spiritual. Humans who have two poles have the freedom to choose between two choices and that choice will determine his destiny. Human philosophy shows that all human beings are related. This brotherhood is the essence of all humanity regardless of racial background, ethnicity, color because all are from the same origin. 
Boisard argues that Islam is more than just an ideology because Islam is a transcendental humanism to implement the teachings to the community so that the community applies moral teachings following philosophical values in the Quran (Boisard 1980, 151). In Islam, humanism does not rule out the concept of absolute monotheism to develop virtue in social life. The implementation of Islam teachings is about tolerance, equality, freedom, and human dignity.

Humanism in Islam should be understood as a humanity basic concept that does not stand alone in a free position because the translation of humanity is always related to theological concept. In this concept, the Quran views humans as God's representative on earth to function as a caliph (Syariati 1982, 111). The humanitarian paradigm is based on the concept that humans are born in a state of fitri (pure). This pure state in nature is then expressed in attitudes that are sacred and good to others (Madjid 1995, 51). Humans consist of physical and spiritual elements as well as individual and social beings. There is always a relationship among one another (Kaelan 2002, 194).

The relationship between God and humans is pictured in human obligation as the creation. Humans need and depend on any conditions to be able to implement teachings to fellow humans-as subject and object. The interaction of subject and object by giving and depending, humans can maintain their existence in life and togetherness.

The concept of religious eschatology which has a concept of the main and basic, at the same time is the origin and purpose of human destiny. The message of his teachings calls for individuals to believe and surrender as a way of salvation. The act of surrender itself is an instrument of building an Islamic social order on earth (Smith 1985, 281). God in Islam is unique in His essence, His attributes, and His actions. He is The Almighty. He invites people to get into His mercy (Boisard 1980, 101). In the concept of Islamic religion, as Wibisono argues in Surajiyo, theocentric values as the basis for human life. God theocentric values must be owned by humans because in essence of the quality of human, it cannot be separated from the divine values (Kaelan 2002, 124).

Humans are free to do anything and are responsible for the contained values as an appreciation to present human's dignity. Therefore, people should believe in God even without intermediaries and intersections, and without the help of guardians (Madjid 1986, 50). 
Human is responsible for his destiny universally in a personal framework concerning God. That is a matter in the context of the logical construction of an Islamic system, namely that the conception of humans can be investigated in terms of juridical as well as philosophical. Humans have privileges because they were chosen by God as khalifah (khalîfat Allâh) on earth.

The values of humanism in Islamic doctrines are developed to implement the concepts of aqeedah, worship, morals, and relationships with fellow human beings for their adherents in the framework of life in the world (al-Qardhawi 1985, 16). That humans are worthless before God leads to a balanced development of humanism. The concept of Islamic values is the power of Islam to protect society against the power of two ideologies, especially liberalism and Marxism.

From these assumptions, Islam rejects the ideological paradigm of liberalism and Marxism as developed in eastern Europe (Russia and China). Because those do not follow the aspects of humanity and divinity in Islam perspective. Philosophically, because in Islam there is a principle of balance and continuity between world life and the hereafter that upholds human values.

The originality of Islamic values is the conception of a social person who opposes communism on one hand and liberalism on another hand who places individuals and communities in opposition (Boisard 1980, 435). Islam teaches humans as God's servants. This position applies to all aspects of life including social, political, economic, and cultural structures (Hasan 1985, 129).

Humanism in Islamic doctrines is not absolute liberalism nor marxism but following the dignity of human values that all creations will return to God. The degree of humanity in life in this world is merely due to Allah and will return to Allah, because all creatures are His. A man was sent on this earth as a caliph to be able to direct all creatures to obey Allah. The concept of humanism in Islam is in harmony with Pancasila. Because Pancasila as the state basis tries to realize the humanity in terms of living together, both concerning physical and spiritual life so that the entire life of Indonesia is always covered by Pancasila principles (Sutoyo 2011, 172). Pancasila as the basis for the implementation of the state of Indonesia can reflect the noble personality and culture of the nation (Panji 2006, 10). Pancasila is truth and reality, psychiatric beauty, goodness or worthiness (morality), as God's creatures (Kaelan 2002, 231). Thus it is clear, that 
Pancasila respects the values of high humanism as the principles of Islamic doctrine.

\section{The Value of Islamic Humanism: Tolerance in Indonesia}

Islam teaches people about tolerance. We can see this in Q.S. alKâfirûn [109]: 1-6, Q.S. Yûnus [10]: 40-41, Q.S. al-Kahf [18]: 29, and many more verses that talk about tolerance. The point is that if God wants all people to believe in Him, this will be done because doing so is easy for Him. However, God's wisdom is still to create human beings in such a way, so that people consider themselves with their choices, whether to believe or disbelieve. Some people will believe and some do not.

Regarding tolerance in Indonesia, based on Desideria's notes, it shows that the number of intolerance continues to increase. Komnas HAM noted, in 2015 there were 87 complaints related to complaints of violations of religion and belief freedom in Indonesia. This number increased compared to 2014 which was only 74 complaints. However, there is still plenty of evidence regarding the attitude of tolerance within society. There are at least four events that show tolerance is present in Indonesian society and could be in the spotlight. First, a portrait of religious tolerance in Karanganyar, Central Java. Ngargoyoso village, at the foot of Mount Lawu, might be a portrait of tolerance. In this village, three places of worship, namely the mosque, church, and temple stand side by side. Good communication and mutual respect make all villagers live in peace despite different beliefs. Second, Jakarta Cathedral Church changed the Mass schedule on Idul Fitri. Cathedral Church in Central Jakarta officials changed the Sunday morning mass schedule to coincide with Idul Fitri this year. This is done so that the churchyard can be used to park Muslims' vehicles who pray at Istiqlal Mosque. Third, Pecalang guards Idul Fitri and Idul Adha prayer. Thousands of Muslims in Denpasar, Bali perform ied prayers in Lumintang Field. Shalat goes solemnly with the security of Hindu police and pecalang. The tradition of tolerance is not only running this year but has been running for years. Fourth, Muslims in Tambrauw, Papua help Christians during celebrations. Interfaith religious tolerance in Tambrauw Regency, West Papua, is a beautiful example. Examples of a culture of tolerance include the committee tasked with celebrating Christian holidays as Muslims and vice versa. Harmony and tolerance are not due to 
government pressure but grow from togetherness in the community by themselves (Desidera 2017).

These conditions indicate that tolerance as part of humanism value still stands tall in Indonesia. Basically, humanism in Indonesian context is an idea that is built with the spirit of nationalism based on religious values (Umam 2019). These religious values can be in the form of culture, good manners, maintaining positive customs, respecting others, and being honest with one another. Humanism in Indonesian context can be said as religious humanism because Indonesia believes in God. Religious humanism in Indonesia has a theocentric pattern (God as the center of everything). Religious humanism comes from various religions in Indonesia. The concept of humanism is at the same time antithetical to the existence of humanism from outside Indonesia which is not following the philosophy of national life, namely secular humanism, Marxism humanism, liberal humanism, and others.

The viewpoint of Islamic humanism is in line with Indonesian context which is based on Pancasila and the 1945 Constitution. Historically, Pancasila was inspired by the values of humanism in Islam. The state is not based on Islam because it considers the heterogeneity of citizens who inhabit the territory of the Republic of Indonesia. However, the problem is how to apply Indonesian humanism values (as stated in Pancasila) in Indonesia to create a united, sovereign, just, and prosperous life. In Indonesian history, the divergence of human values cannot inevitably occur. The confusion of human values has been inspired by a doctrine on teaching that within humans has the concept of individual freedom (Rahardjo 1987, 170). For example, the Greeks at first thought of supernatural mythology, then the paradigm of thinking towards anthropocentricity, power was based on human capabilities, which could then create high civilization and culture (Androngi 1968, 25). Thus God's position is the highest intellectual, so all kinds of intellectuals must surrender to Him (Abbas 1980, 57).

In Indonesia, Pancasila in the operational sphere has a problem. The indication is that many people have abandoned the basic philosophy of Pancasila. We can take examples, the existence of human control over other humans, oppressing the weak, high taxes, prices, and harvest production is lower than the treatment fee. The solution is to improve, adjust, harmonize, implement the concept of Pancasila values so that the context of life will follow. 
By adapting Sukarno's theory of humanism in Indonesian context, he stated that nationalism as a central concept. There was no oppression and coercion; there was freedom of association and issuing opinions (Soekarno 1956, 16). Therefore, Sukarno's style of humanism is in line with the spirit of modernity which upholds theological and humanitarian values. This thought can be analyzed that theologically humans have high enthusiasm to maintain the nobility and dignity based on religious values, so that life can provide the widest possible benefits to other humans. The values of humanism in the theological context have implications that human nature has specific characteristics related to the nobility and dignity that is reflected in society life through tolerance, freedom, and equality of human dignity.

Indonesian people have long been developing tolerance values, but in fact, it has experienced ups and downs. These show that the values are part of Indonesian citizen, especially in Islamic teachings which must be continuously developed in the harmony of religious life in Indonesia. In Islamic perspective, the values of humanism (tolerance) theologically are explained in Quran as, "Say, O you disbelievers, I do not worship what you worship. Nor are you worshippers of what I worship" (Q.S. al-Kâfirûn [109]: 1-3). In Indonesia's context, the theological perspective of humanism can be developed in a life of religious tolerance, by respecting each other's worship and beliefs.

As happened in Kampung Tengah area of East Jakarta, there concerns Islamic and Christian tolerance. Mushala Al-Mukhlishiin which is only about 50 meters from the church shows a high spirit of tolerance. The activity of the two houses of worship colors the daily lives of residents of RT 001 / RW 4 Kampung Tengah, Kramat Jati, East Jakarta. For more than 50 years, Christians and Muslims in this village have lived side by side (Yuniati 2017). Tolerance here means patience, being patient when there is contact with other religions with different opinions or beliefs and allowing other people to carry out religious services (Muhammadin 2017).

In Indonesia concept, tolerance is not only for fellow human beings but also for the universe and environment. This includes respecting each other, caring for each other, understand one another's differences, and helping one another. These acts of tolerance are "open", so religious tolerance in Islam and especially in Indonesia get an important and serious place. The concept of religious tolerance means mutual respect for other different believers and not forcing the will to follow their religion nor to 
interfere each other's religious affairs. Muslims in Indonesia are allowed to cooperate with followers of other religions on economic, social and other worldly aspects (Alpizar 2015).

Religious tolerance in Indonesia is a problem that concerns the existence of each other's beliefs, especially in God. The differences are not a barrier to living in harmony, peace, and co-existence within the framework of fraternity and national unity. The value of awareness in the harmony of religious life must certainly be dynamic, humanist and united to be transformed into the people of the entire country.

\section{The Value of Islamic Humanism: Freedom in Indonesia}

According to Syed Muhammad Naquib Al-Attas, human freedom can be tracked since the primordial covenant signed by each individual before the Creator, as contained in the Quran, surah al-A'râf [7]: 172 and also Q.S. al-Ahzâb [33]: 72. Based on those verses, human freedom has occurred since then (Wan Daud 2003, 100).

In case of freedom, as stated in the 1945 Constitution of Republlic of Indonesia (UUD 1945) article 28 paragraph 3, namely "Everyone has the right to freedom of association, assembly, and issuing opinions." This opinion is not only verbally conveyed as a speech but can also be written. Some cases in Indonesia occur because the opinions in the community are not accepted by the group. One of the popular cases is a controversy in which public figures such as Joshua Suherman and Ge Pamungkas are considered as religious blasphemers as a result of their standup comedy performances. Although what these two people do as comics (people doing standup comedy) is only as a social criticism, they were still targeted by certain groups opposing their opinion. This case occurred in early 2018.

The older case was one related to Warkop DKI in the 1970s when they (Dono, Kasino, and Indro) were still working as radio announcers. They once quipped through Javanese and Betawi conversations. "What does it mean when there is more than three Javanese? Transmigration! Javanese people only trouble out government every year." From this dialogue, it can be said that at that time Warkop DKI was racism toward Javanese. However, Indonesian people just accepted that joke. If at that time there was already Article 156 of the Criminal Law that regulates hatred, animosity, or contempt for a group, then Warkop DKI can be charged for that. This is contrast to Ge Pamungkas and Joshua Suherman who were 
ensnared with religious insult. Such conditions must be put in mind for other Indonesian (Galih 2018).

Freedom as part of humanism value, from Islam perspective in theology as written in Q.S. Yûnus [10]: 99: "And had your Lord willed, those on earth would have believed-all of them entirely. Then, $[O$ Muhammad] would you compel the people in order that they become believers?" The concept in Indonesian context, humans are free to choose because in the end they are the one who are responsible for their behavior. Thus, the meaning of freedom in this context is not freedom as in liberalism which is not associated with the hereafter. Freedom in Indonesia is not absolute because such freedom will only lead to anarchic paradigms. In Indonesia, it is controlled freedom (al-hurriyah al-muqayyadah).

In other thoughts, the value of freedom from an Islamic perspective means that humans are free to choose between good and bad in managing natural resources. The freedom to make choices is inherent in human beings because humans have been given the intellect to think about what is good and what is bad, what is maslahah and which interpretations are beneficial and harmful. That freedom is logical and natural, but one must be responsible for his chosen behavior on earth. The principle of humanism in society which is the reason for dissolution of mass organizations in Perpu Ormas (government regulations substituting for laws concerning mass organizations), is not only things that would oppose the state foundation namely Pancasila but also related to various other reasons such as blasphemy. Perpu Ormas also will not guarantee the freedom of religion in Indonesia, but it will be addressed. It will add to the complexity and new problems of religious freedom in Indonesia (Perppu Ormas Tambah Masalah Baru Bagi Kebebasan Beragama 2017).

The concept of humanism in Indonesian society's life is that humans are guaranteed to have freedom of delivering opinion and expressing (hurriyah al-ta'bîr) as well as other freedoms which are symbols of humanity. In the Quran it is stated that these freedoms are called human rights. Quran verses specifically emphasize the freedom of belief (religion) and the prohibition of coercion in determining the choice of religious beliefs because faith is individual's prerogative and privacy between himself and God (Rodin 2014, 253).

The Ministry of Religion stipulates the concept of Tri Religious Harmony, namely three basic principles used as a basis for religious interfaith in Indonesia. These three are, first, internal harmony among 
religious communities; second, inter-religious harmony; and third, interreligious harmony with the government (Ministry of Religion 1983). Different perceptions about freedom for many types of individual can occur as pictured in the batik industry with various shades and colors; it also represents kinds of religious activities in Indonesia so far (Haryati 2016). The government guarantees the religious life of all citizens of Indonesia and makes Pancasila as the foundation. It then gives religious freedom as stated in the 1945 Constitution article 29. Bhinneka Tunggal Ika (unity in diversity) motto provides the widest possible opportunity for people to follow and perform religious teachings and beliefs based on Pancasila and the 1945 Constitution (Hurmain 2017).

In public life, the state recognizes six official religions i.e. Islam, Christian, Catholic, Hindu, Buddha, and Kong Hu Cu. Plurality in religion will be a threat towards anarchism and break the nation's unity if the state does not provide sufficient guidance for religious harmony.

\section{The Value of Islamic Humanism: Equal Rights in Indonesia}

Islam is a doctrine that places humans in a very high position. Even Quran guarantees the existence of human rights as stated in Q.S. al-Isrâ' [17]: 70. This verse affirms that humans deserves al-karâmah and al-fadîlah. Moreover, the mission of the Prophet is rahmatan lil'alamin, where the benefit/welfare is an offer for all humans and the universe (Lima Hak Asasi Manusia dalam Islam 2017).

In life, the principle of non-discrimination must manifest and be applied in the principle of equality rights and obligations as citizens to condemn the unity and integrity of the nation. Based on this concept, Maarif argues that Indonesian society is open-minded, egalitarian, respectful based on transcendental ethical-moral values derived from the revelations of God (Maarif 2004). With this, it is expected that the building pillars of the nation, state, and religion are strong and are manifested in the following attitudes: (1) all components are treated equally before the law; (2) active participation from the community so that all policies are carried out bottom-up, not top-down; (3) there is a high tolerance among citizens; and (4) there is transparency and clean government (Madjid 1995).

In applying the nationality value, Indonesia as a nation consisting of various ethnicities, religions, races, and sects has a concept of national defense called geostrategic. This conception means that national defense that houses the diversity of society must be able to survive as a sovereign 
nation. In Indonesian context, national security essentially includes state security and welfare for all citizens on earth based on Pancasila (Subiyanto et al. 2018). National resilience must be upheld because there is a culture produced by the West that is incompatible with Indonesian culture which has the potential to erode the value of national integrity (Fuadi 2014, 290). Based on the conceptual and contextual, society must jointly strengthen the network of awareness based on nationalism. Steps that can be taken include all religious leaders, national leaders, and citizens to engage themselves in dialogue and cooperation in all aspects of national and state life. Strengthening the cooperation of religious leaders, community leaders, and state leaders is still relevant to be the injector of the movement so that citizens at the bottom level are protected in the direction of a peaceful and prosperous life.

Maybe many Indonesian people do not feel the same treatment before the law (law can be traded). Maybe that is now the weakness of Indonesia or it can also be said that Indonesian law is limping. That is what ends up hurting people and ultimately people can judge that law they obey can be both fair and not. There are many examples that we can take and contemplate with the rest of Indonesian society. The very opposing cases happened were about a grandmother who stole a piece of chocolate whose case was brought to the court and a case of corruptors. The corruptors have freedom and even extraordinary estrangement before the law including the issue of punishment, facilities that they get in jail or treatment in the law itself (Agung n.d.).

Several other cases in Indonesia reinforce this argument. For example: first, two men named Basar Suyanto and Kholil were sentenced 2 months and 10 days in prison by Kediri District Court, East Java, in 2009 for stealing a watermelon. Because the decision handed down by the Kediri District Court was deemed inhumane, some student representatives protested and supported the two defendants. After a follow-up hearing, finally, the two men were only sentenced 15 days in jail; second, a grandmother, Minah, was sentenced one month in prison with a trial period of 3 months for stealing 3 cacaos worth IDR 2,000 belonged to PT. Rumpun Sari Antan, Banyumas, Central Java. Even though it was returned shortly after being discovered, the management continued to sue her to provide a deterrent effect and so that it was not imitated by other communities. After the verdict was handed down, the company claimed to be satisfied; third, in 2009, a 76-year-old grandfather named Klijo was 
accused of stealing a bunch of bananas, worth IDR 2,000. Starting with a request from a group of children to cut bananas on the side of the road, residents who learned what Mbah Klijo was doing immediately reported it to the police. Many regretted the arrest and direct execution by the authorities to Mbah Klijo considering he was an old man (Diah 2009).

There are still many similar cases in Indonesia that can be said to be sharp downward and blunt upward. It ensnares small people who are blind about law. Not a few people insinuate that the law in Indonesia does not use the principle, "Who is right and who is wrong" but "It is easy to get out for those paying". This condition shows that the value of humanism has not gone as expected. The value, which should be upheld, seems to be defeated by the insistence of lust and momentary interests. Humanism values must be a concern for all parties so it truly becomes part of nation's dignified personality. Equal rights as part of value in Indonesia can be interpreted as people's independence in choosing an action.

Pancasila as the foundation of life philosophy of Indonesia places a high value of dignity and its emphasis is contained in the principle of humanity which is just and civilized. The concept can be formulated into the state's objectives, namely the state's aims to realize people's welfare through justice. Thus, the principle of social justice for all Indonesian people is the core values of the welfare state, to pursue and achieve goals by prioritizing welfare (Kaelan 2014, 381).

Human dignity as citizens uphold human values based on Pancasila and the 1945 Constitution. The principle highly respects and then places the right of human dignity above all things. In the nation's perspective, all rights and dignity owned by humans must be protected, safeguarded and given the right to be fully recognized without any reduction, so that they can live more comfortably and obtain physical and spiritual well-being (Suroto 2015, 310). Human values have been explored and formulated by the nation's leaders. The concept includes; first, Pancasila values are based on the results of philosophical thinking; second, Pancasila values are the most appropriate philosophy of life believed by Indonesian people in social life; and third, Pancasila contains spiritual values which manifestations are following the nature of Indonesian people's conscience (Prasetya 2013, 67).

Pancasila contains the basic values that must be understood. Pancasila's role is as the View of Indonesian Life, the Foundation of Philosophy of the Republic of Indonesia, and the Ideology of Nation (Kaelan 2014, 325). Indonesia has a strong, big, and rich potential. The 
leadership of this nation must be able to build the glory of its people through prosperity without pressure from Eastern and Western worlds. Leaders also dare to say "yes" to truth and justice and "no" to sleaze and tyranny (Ali 2019, 1). To guarantee the essence of human dignity in the Indonesian context, the nation's leaders must be able to create a better idea so that the people Indonesia can dream of sovereign and prosperous society.

\section{Conclusion}

Islamic humanism is very relevant in Indonesian context which has Pancasila as the life philosophy. Because there is an agreement between the human values of Islam perspective and Pancasila, the life harmony emerges where the nation gives nobleness to the high dignity of humans' life.

Tolerance which is part of Islamic humanism still stands tall in Indonesia because people assume that tolerance has high spirit to maintain human's dignity. Although religious friction occurs here and there, in general, it does not reduce the enthusiasm of people to maintain tolerance as part of human values.

Freedom of society in religion, politics, and other fields in Indonesia has been guaranteed by the law, although there are still some restrictions by the government. This limitation often occurs because many people who are overacting in dealing with freedom.

In terms of equal rights, there are still several Indonesian people who feel unfair treatment before the law. It is proven by many lower class people who stole trivial goods get severe penalties. On the other hands, the corruptors stealing huge amount of money have chances to run away from the law. For this reason, the law must stand tall above all, not only sharp downward and blunt upward.

\section{References}

Abbas, Hamzah.1980. Pengantar Filsafat Alam. Surabaya: Al Ikhlas.

Agung, Muput Janu. n.d. "Perlakuan yang Adil dan Sama Didepan Hukum.” http://prasko17.blogspot.com/2012/10/perlakuan-yangadil-dan-sama-didepan.html (August 29, 2019).

Ali, Imam Shamsi. 2019. "Indonesia Butuh Pemimpin Kuat dan Miliki Kapabilitas Mumpuni.” https://www.republika.co.id/berita/kolom/ 
wacana/19/04/03/ppcaef282-indonesia-butuh-pemimpin-kuat-danmiliki-kapabilitas-mumpuni (August 29, 2019).

Ali, Mukti. 1984. "Manusia, Filsafat, dan Tuhan." In Dialog Manusia, Falsafah, Budaya, dan Pembangunan. Malang: Yayasan Pusat Pengkajian, Latihan, dan Pengembangan Masyarakat, 49-69.

Alpizar, Alpizar. 2015. "Toleransi Terhadap Kebebasan Beragama Di Indonesia (Perspektif Islam)." Toleransi: Media Ilmiah Komunikasi Umat Beragama 7(2): 153-67.

DOI: http://dx.doi.org/10.24014/trs.v7i2.1427

Arifin, Zainul. 2014. "Nilai Pendidikan Humanis-Religius." An-Nuha: Jurnal Kajian Islam, Pendidikan, Budaya ES Sosial 1(2): 169-96.

Baisard, Marcel A. 1980. Humanisme Dalam Islam. Trans. M. Rasjidi. Jakarta: Bulan Bintang.

"Begini Kehidupan Toleransi Kristen-Islam di Kampung Tengah di Jakarta Timur." 2017. https://www.tribunnews.com/metropolitan/ 2017/06/29/begini-kehidupan-toleransi-kristen-islam-di-kampungtengah-jakarta-timur (August 29, 2019).

Daudy, Ahmad. 1983. Allah dan Manusia Dalam Konsepsi Syeh Nuruddin Ar Raniry. Jakarta: Rajawali Pers.

Desideria, Benedikta. 2017. "4 Bukti Toleransi Masih Hadir di Indonesia." https://www.liputan6.com/health/read/3165084/4-bukti-toleransimasih-hadir-di-indonesia (August 29, 2019).

Diah, Diah. 2009. "7 Kasus Hukum di Indonesia yang "Terkesan Tajam ke Bawah, Tumpul ke Atas." https://www.boombastis.com/hukum-diindonesia/58772 (August 29, 2019).

Drijakara, S. J. 1969. Filsafat Manusia. Yogyakarta: Kanisius.

Fakhruddin, Fakhruddin. 2016. "Konsep Humanistik Ditinjau Dari Perspektif Pendidikan Islam." Fokus: Jurnal Kajian Keislaman dan Kemasyarakatan 1(2): 137-58.

DOI: http://dx.doi.org/10.29240/jf.v1i2.128

Fuadi, Maimun. 2014. "Budaya Lokal Versus Budaya Global." Jurnal AtTuras: Jurnal Studi Keislaman 1(2): 290-305. 
DOI: https://doi.org/10.33650/at-turas.v1i2.163

Galih, Rafael. 2018. "Bebas berpendapat di Indonesia Apakah Bebas?." https://www.kompasiana.com/rafaelgalih/5a70927adcad5b6e7676 d6c3/bebas-berpendapat-di-indonesia-apakah-bebas (August 29, 2019).

Gazalba, Sidi, 1978. Ilmu Filsafat Dan Islam Tentang Manusia. Jakarta: Bulan Bintang.

Haryati, Tri Astutik. 2016. "Kematangan Beragama Masyarakat Industri Batik." Jurnal Penelitian 13(2): 173-86.

DOI: https://doi.org/10.28918/jupe.v13i2.1199

Hasan, Rifai A. 1985. Perspektif Islam Dalam Pembangunan Bangsa. Yogyakarta: PLP2M

Hurmain, Abu Bakar. 2016. "Kerukunan Antarumat Beragama: Telaah atas Piagam Madinah dan Relevansinya Bagi Indonesia.” Toleransi: Media Ilmiah Komunikasi Umat Beragama 8(2): 204-16.

DOI: http://dx.doi.org/10.24014/trs.v8i2.2479

Kaelan, Kaelan. 2002. Filsafat Pancasila. Yogjakarta: Paradigma.

Kaelan, Kaelan. 2014. Pendidikan Pancasila. Yogyakarta: Paradigma.

"Lima Hak Asasi Manusia dalam Islam." 2017. https://islam.nu.or.id/post/read/83369/lima-hak-asasi-manusiadalam-islam (August 29, 2019).

Maarif, Syafii. 2004. Mencari Autentisitas Dalam Kegalaua. Yogyakarta: PSAP.

Madjid, Nurcholis, 1986. Islam Sebuah Dilema. Bandung: Mizan.

Madjid, Nurcholis.1995. Islam Agama Kemanusiaan: Membangun Tradisi dan Visi Baru Islam Indonesia. Jakarta: Yayasan Wakaf Paramadina.

Ministry of Religion. 1971. Al-Qur'an dan Terjemahannya. Jakarta: Yayasan Penyelenggara Penterjemah al-Qur'an Departemen Agama.

Ministry of Religion. 1983. Pedoman Dasar Kerukunan Hidup Beragama. Jakarta: Proyek Pembinaan Kerukunan Hidup Umat Beragama. 
Misbah, T. Lembong. 2014. "Humanisme Religius: Menyingkap Wajah Islam yang Ramah.” Jurnal Al Bayan: Media Kajian dan Pengembangan Ilmu Dakwah 20(1): 12-35.

DOI: http://dx.doi.org/10.22373/albayan.v20i29.116

Muhaimin and Abdul Mujib. 1993. Pemikiran Pendidikan Islam. Bandung: Trigenda Karya.

Muhammaddin, Muhammaddin. 2017. "Islam dan Humanisme." Jurnal Studi Agama 1(2): 64-86

Nelson, Zulkifli, and Dardiri Dardiri. 2016. "Inklusivisme dan Humanisme Pesantren.” Toleransi: Media Ilmiah Komunikasi Umat Beragama 8(2): 134-51.

DOI: http://dx.doi.org/10.24014/trs.v8i2.2475

Panji, Setiaji. 2006. Pendidikan Pancasila: Perspektif Sejarah Perjuangan Bangsa. Jakarta: Grasindo.

"Perppu Ormas Tambah Masalah Baru Bagi Kebebasan Beragama." 2017. https://www.merdeka.com/peristiwa/perppu-ormas-tambahmasalah-baru-bagi-kebebasan-beragama.html (August 29, 2019).

Prasetyo, Teguh. 2013. Hukum dan Sistem Hukum berdasarkan Pancasila. Yogyakarta: Media Perkasa.

al-Qardhawi, Yusuf. 1985. Extremis Islam. Bandung: Mizan.

Rahardjo, Dawam. 1987. Insan Kamil: Konsepsi Manusia Menurut Islam. Jakarta: Grafiti Pers.

Rodin, Dede. 2014. "Riddah dan Kebebasan Beragama Dalam Al-Quran." Ahkam: Jurnal Ilmu Syari'ah 14(2): 253-67.

DOI: $10.15408 /$ ajis.v14i2.1284

Setjoatmodjo, Pranjoto. 1984. "Pembaharuan Konsep Kemanusiaan Dalam Pendidikan.” In Dialog Manusia, Falsafah, Budaya, dan Pembangunan. Malang: Yayasan Pusat Pengkajian, Latihan, dan Pengembangan Masyarakat, 125-38.

Smith, Donald Eugene. 1985. Agama di Tengah Sekularisasi Politik. Trans. Azyumardi Azra. Jakarta: Penerbit Panji Mas.

Soekarno. 1956. Indonesia Menggugat. Jakarta: Penerbitan S. K. SENO. 
Soelaeman, M.I. 1988. Suatu Telaah Tentang Manusia, Religi, Pendidikan. Jakarta: LP2LPTK.

Subiyanto, Adi. Rizaldi Boer, Edvin Aldrian, Perdinan Perdinan, and Rilus Kinseng. 2018. "Isu Perubahan Iklim Dalam Konteks Keamanan dan Ketahanan Nasional." "Jurnal Ketahanan Nasional: Graduate School Universitas Gadjah Mada 24(3): 287-305.

DOI: https://doi.org/10.22146/jkn.37734

Suroto, Suroto. 2015. "Harkat dan Martabat Manusia Dalam Pandangan Kenegaraan Pancasila dan UUD NRI Tahun 1945.” Jurnal Pembaharuan Hukum 2(3): 310-8.

DOI: http://dx.doi.org/10.26532/jph.v2i3.1508

Syaifullah, Ali. 1984. "Citra Manusia Budaya Menurut Kaum Eksistensialis.” In Dialog Manusia, Falsafah, Budaya, dan Pembangunan. Malang: Yayasan Pusat Pengkajian, Latihan, dan Pengembangan Masyarakat, 139-71.

Syariati, Ali. 1982. Sosiologi Islam. Trans. Saifullah Wajyudin. Yogyakarta: Ananda.

Syariati, Ali, 1984. Tugas Cendikiawan Muslim. Trans. Amin Rais. Jakarta: Rajawali.

Tamara, M. Nasir and Saiful Anwar Hashem. 1996. "Pengantar: Agama dan Dialog Antar Peradaban.” In Agama dan Dialog Antar Peradaban. Jakarta: Paramadina, xi-xxiii.

Umam, Fawaizul. 2019. "Ideological Involution of The Islamists." Ulul Albab: Jurnal Studi Islam 20(1): 25-45.

DOI: http://dx.doi.org/10.18860/ua.v20i1.5714

Wan Daud, W.M.N. 2003. Filsafat dan Praktek Pendidikan Syed Naquib alAttas. Trans. Hamid Fahmy Zarkasyi et al. Bandung: Mizan. 